\title{
Recent changes in distribution and relative abundance of cetaceans in the Norwegian Sea and their relationship with potential prey
}

\author{
Leif Nøttestad $^{1 *}$, Bjørn A. Krafft ${ }^{1}$, Valantine Anthonypillai ${ }^{1}$, Matteo Bernasconi ${ }^{1}$, Lise Langård ${ }^{1,2}$, \\ Herdis L. Mørk ${ }^{1}$ and Anders Fernö ${ }^{1,3}$ \\ ${ }^{1}$ Institute of Marine Research, Bergen, Norway \\ 2 Directorate of Fisheries, Bergen, Norway \\ ${ }^{3}$ Department of Biology, University of Bergen, Bergen, Norway
}

\section{Edited by:}

Tore Haug, Institute of Marine

Research, Norway

Reviewed by:

Nathaniel Kenneth Newlands, Department of Agriculture and Agri-Food Canada, Canada Gísli Arnór Víkingsson, Marine Research Institute, Iceland

\section{*Correspondence}

Leif Nottestad, Institute of Marine

Research, Research Group on

Pelagic Fish, Nordnesgaten 33,

NO-5817 Bergen, Norway

e-mail: leif.nottestad@imr.no
This study aimed to assess possible shifts in distributional patterns of cetaceans residing in the Norwegian Sea, and to relate the distribution to their feeding ecology during the summer seasons of 2009, 2010, and 2012. During this same period, historically large abundances in the order of 15 million tonnes pelagic planktivorous fish such as Norwegian spring-spawning herring (Clupea harengus), northeast Atlantic mackerel (Scomber scombrus) and blue whiting (Micromesistius poutassou), have been reported feeding in the Norwegian Sea during the summer. There is also observed elevated average surface temperatures and a reduction in zooplankton biomass during the last two decades. Such changes might influence species composition, distribution patterns and feeding preferences of cetaceans residing the region. Our results show higher densities of toothed whales, killer whales (Orcinus orca) and pilot whales (Globicephala melas), than the previous norm for these waters. Baleen whales, such as minke whales (Balaenoptera acutorostrata) and fin whales (Balaenoptera physalus), which are often associated with macro-zooplankton, displayed a distribution overlap with pelagic fish abundances. Humpback whales (Megaptera novaeangliae) were observed in low numbers, indicating a shift in habitat preference, compared to sighting data collected only few years earlier. Our study illustrate that both small and large cetaceans that reside in the Norwegian Sea have the capability to rapidly perform shifts in distribution and abundance patterns strongly associated with adaptive search behavior in relation to both changing levels of abundance in their prey and elevated sea-surface temperatures. This study provides new evidence on high ecological plasticity in response to changing predator-prey trophic relationships and elevated sea-surface temperatures.

Keywords: whales, dolphins, spatial distribution, shift, feeding, pelagic fish, climate change

\section{INTRODUCTION}

Marine mammal distributional shifts as a consequence of a warming climate are reported worldwide (Würsig et al., 2002; Moore and Huntington, 2008; Ferguson, 2009; Simmonds and Elliot, 2009; Smith and Reeves, 2010; Kovacs et al., 2011). Certain freshwater systems and Arctic related regions, currently undergoing the most rapid climatic changes, experience the most profound effects particularly with the small and especially niche dependent cetaceans (IPCC, 2007, 2014; Burek et al., 2008; Moore and Huntington, 2008; NAMMCO, 2013). A number of recent reviews concerning the possible impact of climate change upon marine mammals predict that their distribution, prey preference and long term recruitment will be affected (IWC, 1997, 2009; Learmonth et al., 2006; Burek et al., 2008; Laidre et al., 2008; Moore and Huntington, 2008; MacLeod, 2009; Evans et al., 2010).

Since the initiation in 1978 of systematic collections of hydrological data from the Norwegian Sea, the annual average temperature and salinity has increased $1^{\circ} \mathrm{C}$ and $0.1 \mathrm{PSU}$, respectively (Skjoldal et al., 2004). Large variations are also reported in distribution and abundances of pelagic planktivorous fish, which are important as prey for many of the large cetacean species, but there are still uncertainties about the causal mechanisms behind these fluctuations (Holst et al., 2004). Little information on whale feeding ecology exists from this ecosystem but it is regarded, especially during the summer seasons, as an important foraging ground and transit route to and from higher latitudes (Jonsgård, 1966, 1968; Øien, 1988, 2003, 2013; Christensen et al., 1992; Nøttestad and Olsen, 2004; Pike et al., 2005). Despite ascertainable changes in the whale prey communities in the Norwegian Sea, no clear changes in fin- (Balaenoptera physalus) or humpback whale (Megaptera novaengliae) distribution patterns were detected in a study investigating sighting data collected during 2006 and 2007 (Nøttestad et al., 2014a), compared to distributional trends reported 10-15 years earlier (Skjoldal et al., 2004; 
Vikingsson et al., 2009). A recent study on offshore-feeding killer whales (Orcinus orca) in this system found that they mainly targeted northeast Atlantic mackerel (Scomber scombrus) (Nøttestad et al., 2014b). This was in contrast to the earlier perception that their main prey was the Norwegian spring-spawning (NSS) herring (Clupea harengus) (Sigurjónsson et al., 1988; Similä et al., 1996; Simon et al., 2006). This has been the case at least for the more coastal areas, but no such focused large scale study prior to Nøttestad et al. (2014b) had given attention to the offshore areas of this highly productive marine ecosystem. Furthermore, the collective behavior of killer whales have been found fine-tuned to prey schooling size and behavior (Nøttestad et al., 2002, 2014b).

However, over the last few years even more striking changes in prey species composition are reported from this system; the northeast Atlantic mackerel stock has showed a dramatic estimated increase in abundance from 1.6 million tonnes (Mt) in 2007 to $9.0 \mathrm{Mt}$ in 2014 (ICES, 2013b, 2014; Nøttestad et al., 2014c). The NSS herring biomass has recently decreased from $>12 \mathrm{Mt}$ in 2009 to $<5 \mathrm{Mt}$ in 2014 (ICES, 2013b, 2014), and the Atlantic blue whiting (Micromersitius poutassou) biomass decreased from a spawning stock biomass of nearly $8 \mathrm{Mt}$ in 2002 to 2.9 and $5.5 \mathrm{Mt}$ in 2010 and 2014 respectively (ICES, 2013b, 2014).

In light of the updated knowledge on the shifts in important cetacean prey-changes in distribution, biomass and species composition, we aim to better determine and assess how temporal changes in distributional patterns can be distinguished and possibly how the role of phenotypic plasticity (the ability of an organism to change its phenotype in response to changes in the environment) acts for different cetacean species residing the Norwegian Sea. We will investigate the most recent cetacean sighting data from this area, conducted during three synoptic summer surveys in 2009, 2010, and 2012, by studying its possible relationships to measurements of prey distribution and by including other key environmental variables.

\section{MATERIALS AND METHODS}

Three transect surveys were undertaken in the Norwegian Sea from the 15th of July to the 6th of August in 2009 and 2010, and from the 1st to the 28th of July in 2012. In total four different Norwegian vessels were chartered for the purpose of this study: M/V "Libas” (2009 and 2010), M/V “Eros” (2009), M/V "Brennholm" (2010 and 2012), and the research vessel R/V "G.O. Sars" (2012). The geographical coverage and data collection in 2011 were too limited in the northern part of the Norwegian Sea to be included in the time series. Only one Norwegian vessel, compared to two vessels participating the other years and no dedicated marine mammal observers were present onboard in 2011. The geographical area covered by the survey was very similar the two first seasons, while the most northern part was not covered during the survey in 2012 (Figures 1-3).

Marine mammal sightings were made by two trained and experienced whale observers on each vessel along the survey tracks during daylight hours (about $10-12 \mathrm{~h}$ per day). Furthermore, opportunistic sightings were also performed between stations from the bridge during nighttime, when applicable, since the light regime was dominated by midnight sun.
It was therefore sufficient sunlight for reliable visual sightings of marine mammals up to $24 \mathrm{~h}$ per day when the surveys were conducted in high latitudes from July to August. Thus, most of the track lines were surveyed either by dedicated or opportunistic effort and the effort was comparable between the years 2009, 2010, and 2012 as well as to the previous sighting surveys. Sightings were made mostly from a platform at the wheelhouse rooftop (11-15 m height depending on vessel) whenever weather permitted (Beaufort $<4$ and no or moderate rain). The sightings were otherwise made from the bridge (9-13 $\mathrm{m}$ height). The marine mammal sightings were done along transects and during transit between transects, however no recordings were made while trawling or when performing other station work. Observations were made using the observation regime adopted by Palka and Hammond (2001) and Lawson and Gosselin (2009). A sighting was noted on the basis of direct observation with the naked eye and binoculars, and was documented with digital video-recordings and photographs. This procedure ensured valid estimates and verification of marine mammal group size related to each sighting. Both passing and closing mode were applied during sightings of marine mammals. In a passing mode, the ship moves continuously along a transect line, whereas in a closing mode, the ship stops normal searching procedures once a group of cetaceans is sighted (goes "off-effort"), leaves the transect line and approaches the sighted group to identify the species and stock composition of the group and make reliable estimates of group size (Schwartz et al., 2010). The survey design had predominantly east-west transects with 35-60 nautical miles distance between survey lines. Combined with high survey speed of 10-12 knots for all vessels in all years, this ensured that the risk of double counting for both pelagic fish and marine mammals was absent or extremely low. The sighting data were not corrected for surfacesighting probability. Very good wind and weather conditions with optimal sighting conditions dominated during these summer surveys. Nevertheless, the aim of these surveys was not to perform quantitative abundance estimation of marine mammals, rather studying distribution, relative abundance and ecological aspects of a wide range of marine mammals present in the Norwegian Sea ecosystem.

In total, 334 CTD (Conductivity Temperature Depth) casts ( $n=93$ in 2009, $n=152$ in 2010 and $n=89$ in 2012) were performed using SAIV and SEABIRD sensors. The CTDs were deployed from surface to $500 \mathrm{~m}$ depth and the stations were spaced approximately $\sim 110 \mathrm{~km}(60 \mathrm{nmi})$ apart along the transect lines, although less distance $(35-50 \mathrm{nmi})$ between transect lines and stations were done in the northernmost regions.

Meso- and macro-zooplankton were sampled at each pelagic trawl station using a WP2 net with a diameter of $56 \mathrm{~cm}$ and mesh size of $180 \mu \mathrm{m}$. A total of $333 \mathrm{WP} 2$ vertical hauls were carried out from $200-0 \mathrm{~m}$ ( $n=93$ in 2009, $n=152$ in 2010 and $n=88$ in 2012). Zooplankton biomass was calculated to total dry weight in $\mathrm{g} \mathrm{m}^{-2}$ using the methods described in Gjøseter et al. (2000).

A total of 348 trawl hauls ( $n=93$ in 2009 and $n=148$ in 2010 and $n=107$ in 2012) were made at pre-defined positions, using a commercial blue whiting pelagic trawl net (Egersund trawl in 2010), Atlantic salmon adapted pelagic trawl (2009) and a pelagic sampling trawl (Multpelt 832 in 2012). Trawl depths 


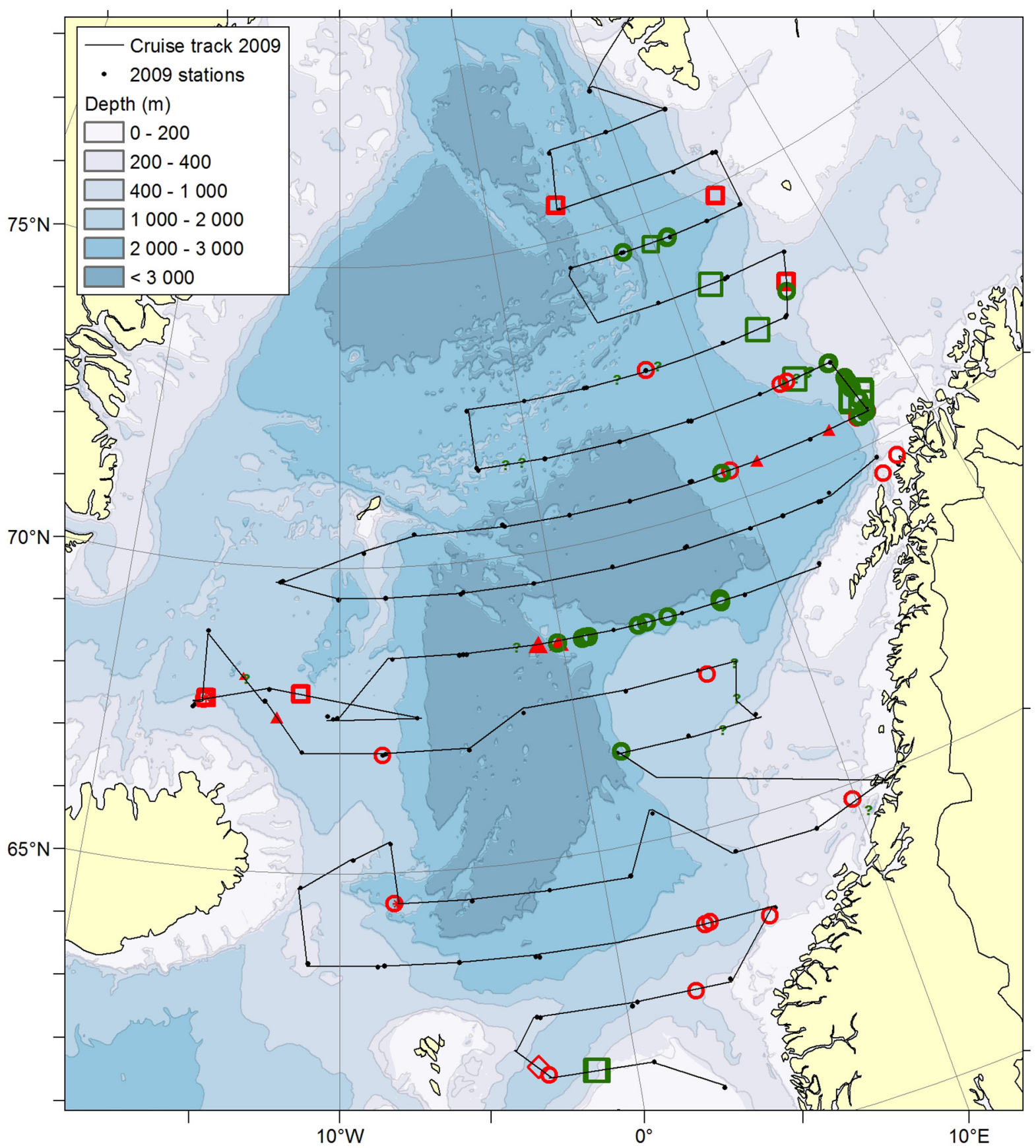

\begin{tabular}{|c|c|c|c|c|}
\hline $\begin{array}{l}\text { Killer whales } \\
\Delta 1-3 \\
\Delta 4-10 \\
\Delta 11-35\end{array}$ & $\begin{array}{l}\text { Pilot whales } \\
\qquad 1-3 \\
4-10 \\
11-35\end{array}$ & $\begin{array}{l}\text { Minke whales } \\
\text { O } 1 \text { - } 3 \\
\mathbf{O}^{4-10} \\
11-35\end{array}$ & 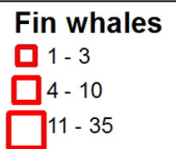 & $\begin{array}{l}\text { Humpback whales } \\
* 1-3 \\
* 4-10 \\
* 11-35\end{array}$ \\
\hline $\begin{array}{l}\text { Sperm whales } \\
\text { O } 1 \text { - } 3 \\
\mathrm{O}^{4-10} \\
\mathrm{O}_{11-35}\end{array}$ & $\begin{array}{l}\text { White beak. dol. } \\
+1-3 \\
+4-10 \\
+11-35\end{array}$ & $\begin{array}{l}\text { Dolphin sp } \\
\begin{array}{l}\square-3 \\
\square \\
\square-10 \\
\square 11-35\end{array}\end{array}$ & $\begin{array}{l}\text { Unidentified } \\
? 1-3 \\
? 4-10 \\
? 11-35\end{array}$ & whales \\
\hline
\end{tabular}

FIGURE 1 | Distribution of cetaceans sighted in the Norwegian Sea during the summer season of year 2009. Black lines illustrate cruise tracks from two vessels, whereas black dots represent stations for pelagic trawl sampling of pelagic fish, plankton nets (0-200 m) and physical oceanography from CTD (0-500 $\mathrm{m}$ ). 


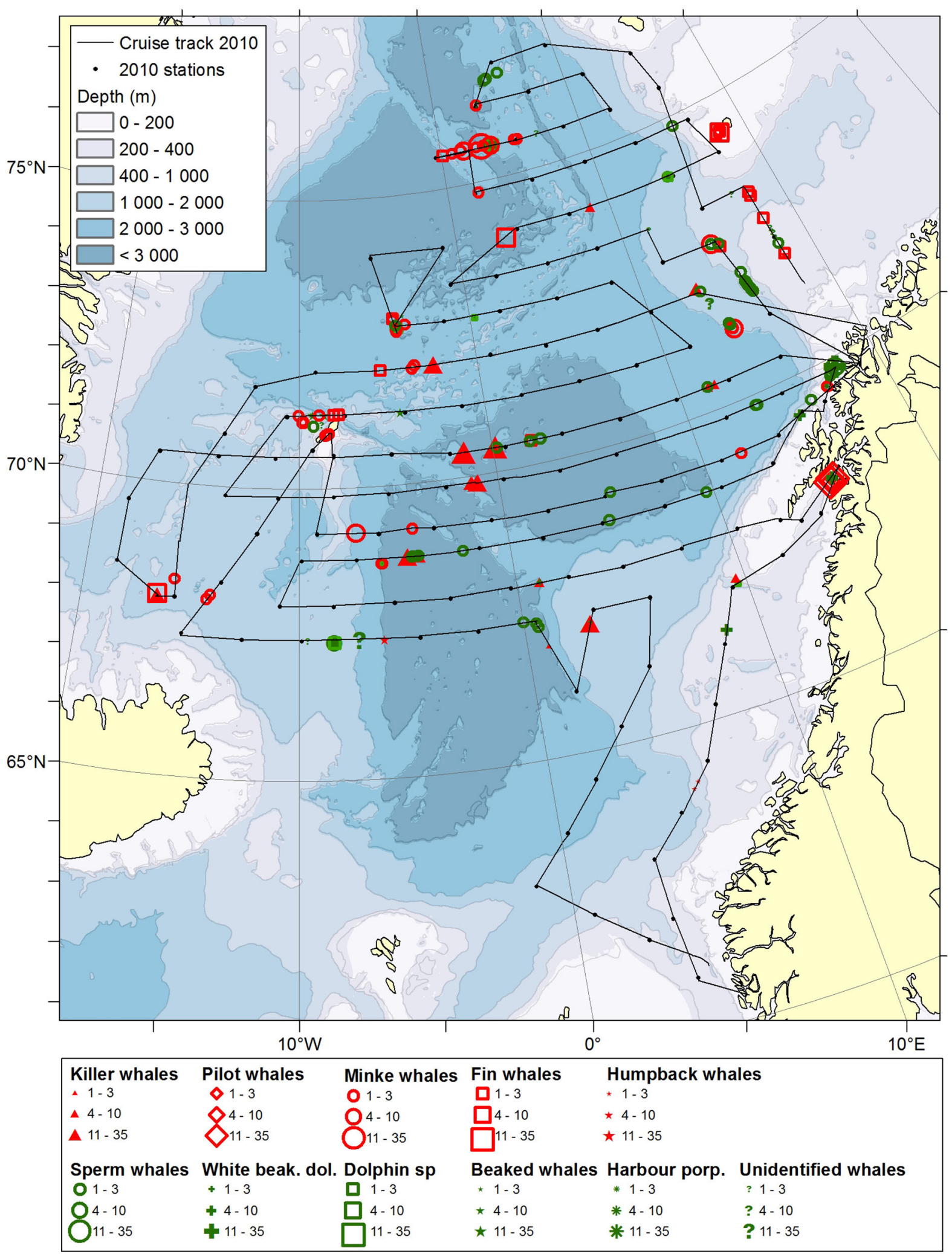

FIGURE 2 | Distribution of cetaceans sighted in the Norwegian Sea during the summer season of year 2010. Black lines illustrate cruise tracks from two vessels, whereas black dots represent stations for pelagic trawl sampling of pelagic fish, plankton nets (0-200 m) and physical oceanography from CTD (0-500 $\mathrm{m}$ ). 


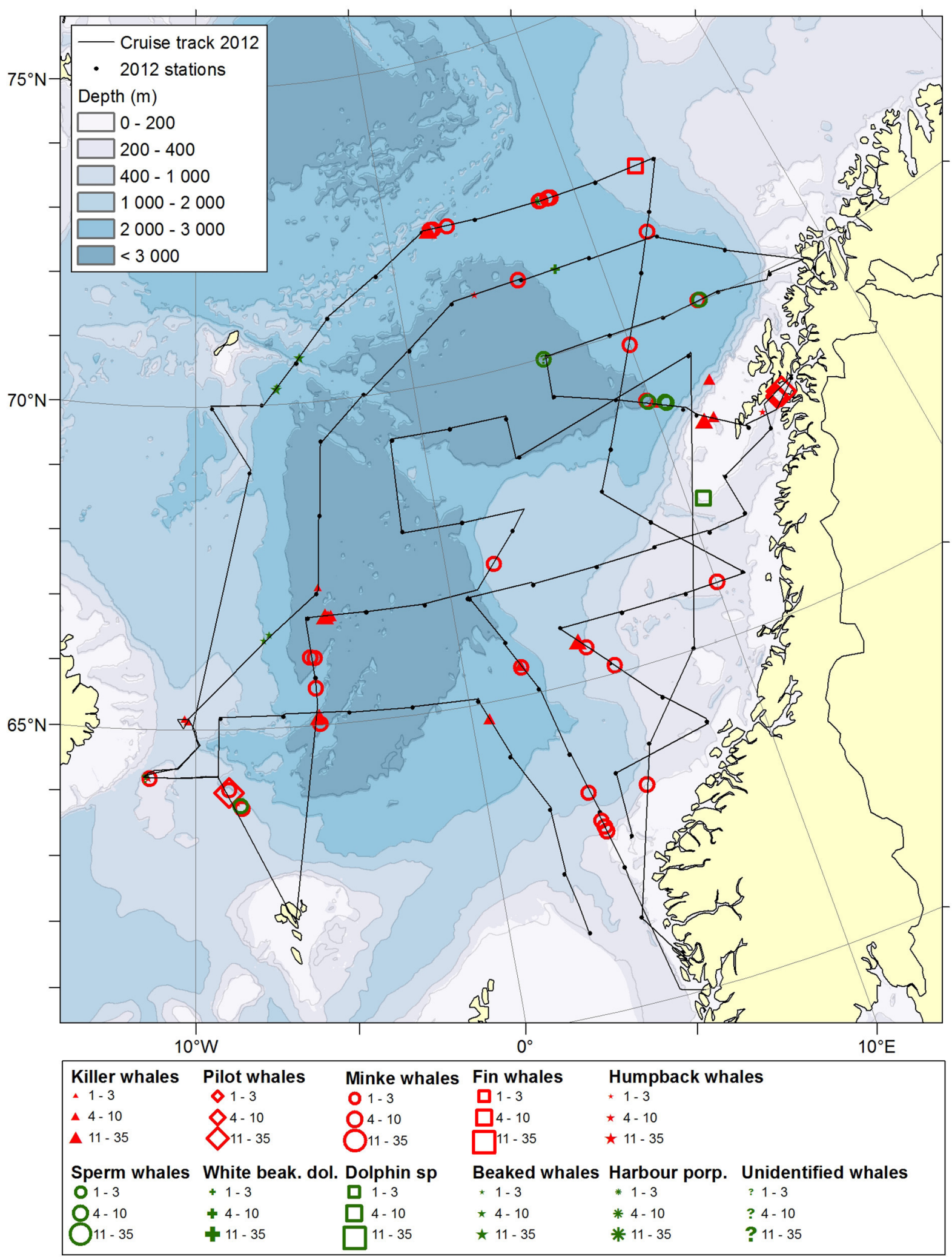

FIGURE 3 | Distribution of cetaceans sighted in the Norwegian Sea during the summer season of year 2012. Black lines illustrate cruise tracks from two vessels, whereas black dots represent stations for pelagic trawl sampling of pelagic fish, plankton nets and physical oceanography from CTD (0-500 m). 
ranged from 0-60 $\mathrm{m}$, towing speed was 4.0-5.3 knots and towing duration was set to $\sim 30 \mathrm{~min}$. Towing distance during trawling varied between 3.7 and $4.9 \mathrm{~km}$, corresponding to 4.0 and 5.3 knots respectively, depending on currents and weather conditions. The catches were sorted, identified to species and weighed. The accuracy on the total fish catches from pelagic trawling was around $\pm 10 \mathrm{~kg}$, whereas individual sorted fish samples had an accuracy of $\pm 1 \mathrm{~g}$.

Complete stations conducted by combining CTD sampling, plankton nets and standardized pelagic trawl hauls were included as predictor variables in a Generalized Additive Model (GAM) nonparametric regression analysis, using the Gaussian distributional fit (SAS Institute Inc., Box 8000 Cary, N.C., U.S.A). The most common prey species in the study area were included (\#kg in catch) [NEA mackerel, NSS herring, Atlantic blue whiting, capelin (Mallotus villosus), krill and gonatus (Gonatus fabricii) (Tables 3A,B)] and environmental variables (sub-surface temperature $\left({ }^{\circ} \mathrm{C}\right)$ and bottom depth $(\mathrm{m})$ as close as possible to the actual position of a sighting. Bottom depth was extracted from the General Bathymetric Chart of the Ocean (GEBCO: www. gebco.net). Response variables included number of individuals of a cetacean species or absence of marine mammals observed during the entire study, within 20-30 nmi distance from each station depending on northern latitude. Since the sightings of marine mammals are continuous data and the oceanographic and biological data originates from station data spaced 20-30 nmi apart, we need to make assumptions on overlap based on different spatial resolution of the different sources of information. The 0.05 level of probability was accepted as indicating statistical significance and all mean values are shown \pm standard deviations.

\section{RESULTS}

\section{TOOTHED WHALES}

Killer whale was the most common cetacean species observed during all three study years, followed by pilot whales (Table 1). Killer whales had $N=48$ individuals in 2009, $N=136$ in 2010 and $N=182$ in 2012. Pilot whales had $N=6$ individuals in 2009, $N=31$ in 2010 and $N=114$ in 2012. Killer whales and pilot whales had also the highest observed group sizes among the marine mammals (Table 2). Killer whale group size varied from an average 5.1-9.2 animals whereas pilot whale group size varied from an average of 5.2-17.0 animals between years.

Killer and pilot whales increased significantly in appearance in the Norwegian Sea during the consecutive study years, whereas the sperm whale numbers decreased (Table 1).

Killer whales were positively correlated with distribution and concentrations of Northeast Atlantic mackerel $(p<0.0001$, $n=402)$ (Table 3A) and shallow bottom depths $(p<0.0072$, $n=402$ ) when pooling the data for all years. They were positively correlated with high concentrations of mackerel for the years 2010 $(t=3.73, d f=179, p<0.001)$ and $2012(t=3.04, d f=116$, $p<0.005)$.

Pilot whales were significantly correlated with high concentrations of NSS herring ( $p=0.0002, n=380)$ (Table 3A), and shallow bottom depths $(p=0.0002, n=380)$. Pilot whales were solely observed in shallower waters than $300 \mathrm{~m}$ depth.
Table 1 | Overview of number of individuals from different cetacean species sighted in 2009, 2010, and 2012.

\begin{tabular}{lccc}
\hline Species/Year & $\mathbf{2 0 0 9}$ & $\mathbf{2 0 1 0}$ & $\mathbf{2 0 1 2}$ \\
\cline { 2 - 4 } & & Numbers & \\
\hline Killer whales & 48 & 136 & 182 \\
Pilot whales & 6 & 31 & 114 \\
Minke whales & 26 & 60 & 31 \\
Fin whales & 7 & 20 & 2 \\
Humpback whales & 4 & 8 & 8 \\
Sperm whales & 36 & 49 & 8 \\
White beaked dolphin & 0 & 20 & 4 \\
Dolphin sp & 67 & 22 & 1 \\
Beaked whales & 0 & 11 & 20 \\
Unidentified whales & 34 & 33 & 2 \\
Harbor porpoises & 0 & 4 & 1 \\
\hline
\end{tabular}

Table 2 | Overview of average group size $( \pm S D)$ from cetacean species sighted in 2009, 2010, and 2012.

\begin{tabular}{lccc}
\hline Species/Year & $\mathbf{2 0 0 9}$ & $\mathbf{2 0 1 0}$ & $\mathbf{2 0 1 2}$ \\
\cline { 2 - 4 } & \multicolumn{3}{c}{ Group size (士SD) } \\
\hline Killer whales & $6.0(5.9)$ & $5.1(5.7)$ & $9.2(6.1)$ \\
Pilot whales & $6.0(0.0)$ & $5.2(3.3)$ & $17.0(11.9)$ \\
Minke whales & $1.1(0.3)$ & $1.2(0.6)$ & $1.0(0.0)$ \\
Fin whales & $1.3(0.5)$ & $1.3(0.6)$ & $2.0(0.0)$ \\
Humpback whales & $2.0(1.4)$ & $1.6(0.9)$ & $1.1(0.4)$ \\
Sperm whales & $1.1(0.3)$ & $1.0(0.1)$ & $1.3(0.8)$ \\
White beaked dolphin & $0.0(0.0)$ & $4.7(4.7)$ & $1.0(0.0)$ \\
Dolphin sp & $9.6(7.6)$ & $2.8(1.3)$ & $1.0(0.0)$ \\
Beaked whales & $0.0(0.0)$ & $3.0(4.0)$ & $3.3(1.0)$ \\
Unidentied whales & $1.4(0.8)$ & $2.4(0.8)$ & $1.0(0.0)$ \\
Harbor porpoises & $0.0(0.0)$ & $1.0(0.0)$ & $1.0(0.0)$ \\
\hline
\end{tabular}

Harbor porpoises were only found significantly associated with shallow waters $(p=0.0167, n=373)$.

Beaked whales were found associated with NSS herring $(p<$ $0.0001, n=380)$ and deep bottom depths $(p=0.0354, n=380)$.

White beaked dolphins were significantly correlated with shallow water $(p=0.0073, n=372)$ and were predominantly observed along the shelf break. The unidentified dolphin species were significantly correlated with biomasses of zooplankton ( $p=$ 0.0195, $n=377)$ and low temperatures $(p=0.0142, n=377)$.

Total numbers of sperm whales sighted were $N=36$ in 2009, $N=49$ in 2010, and $N=8$ in 2012, respectively (Table 1). These sightings were not found significantly correlated with the distribution or concentrations of any of the prey species, nor environmental variables included in the regression model.

\section{BALEEN WHALES}

Minke whale was the most sighted baleen whale in $2009(N=$ 26), $2010(N=60)$, and $2012(N=31)$. Minke whales were significantly correlated with the occurrence of NSS herring $(t=$ 5.71, $d f=416, p<0.0001)$, but no such relationship were 
Table 3A | Regression model components (most common available prey), and results from the GAM procedure analyzing their relationship to toothed whale species densities.

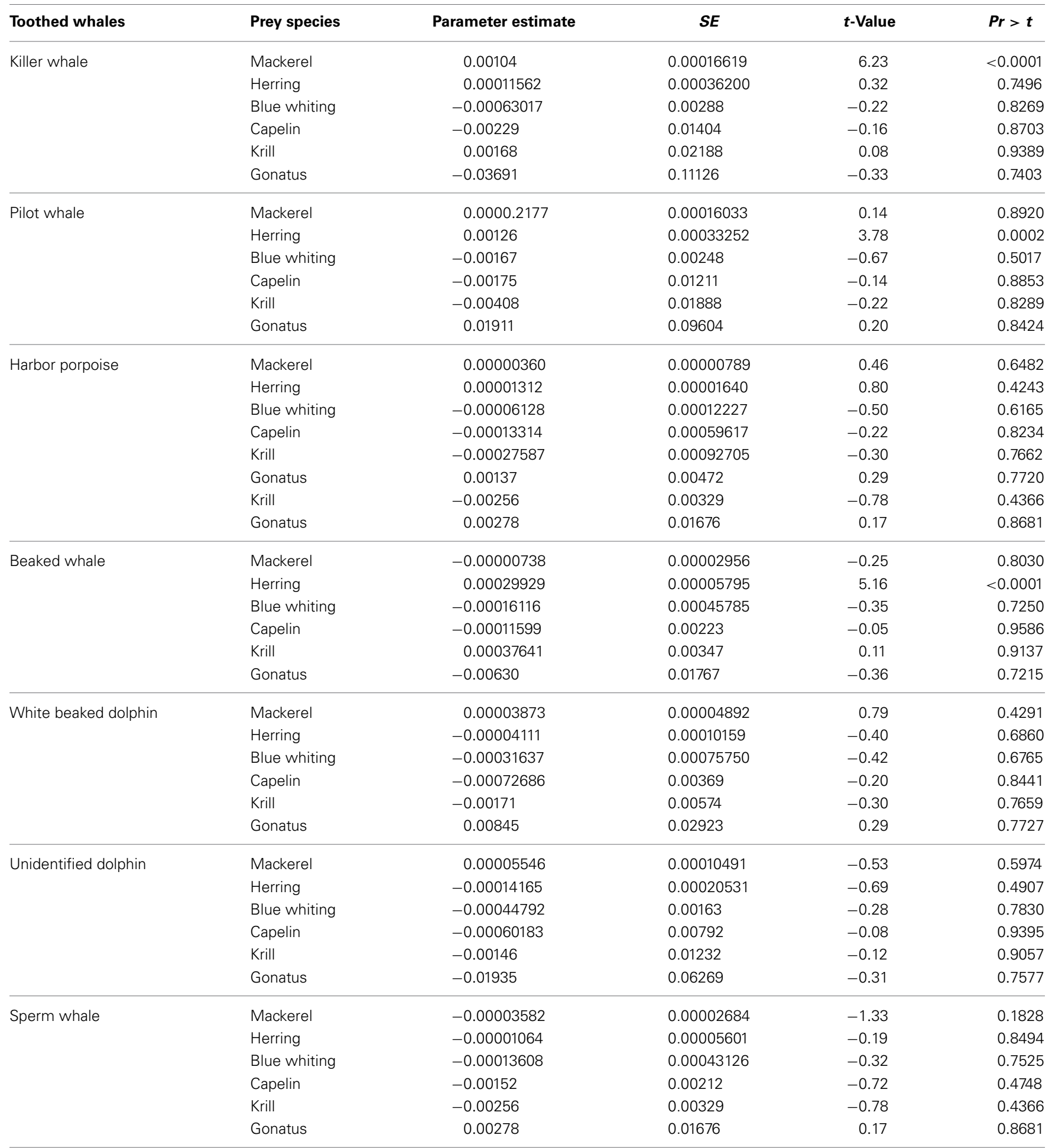

found for zooplankton $(t=1.67, d f=416, p<0.095)$ when combining all years (Table 3B).

Fin whales and humpback whales were observed with lower numbers and smaller group sizes in the study area between 2009 and 2012 (Tables 1, 2). Fin whales were significantly correlated with distribution and high concentrations of capelin $(p=0.0017$, $n=376)$, low temperatures $(p=0.0026, n=376)$ and shallow bottom depths $(p<0.05, n=376)$ (Table 3B). 
Table 3B | Regression model components (most common available prey), and results from the GAM procedure analyzing their relationship to baleen whale species densities.

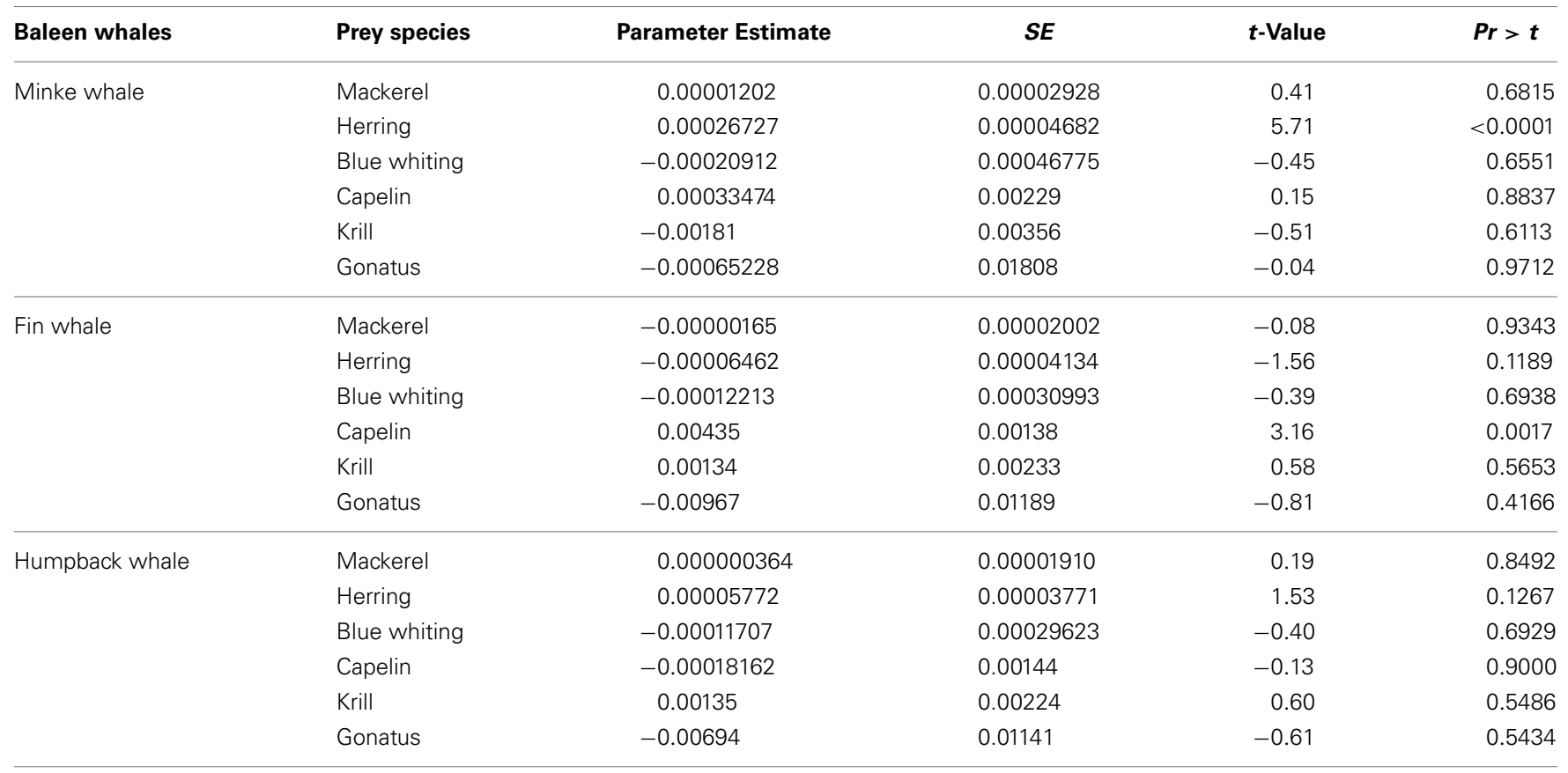

Humpback whales were not significantly correlated with distribution and concentrations of any of the selected regression model components such as pelagic fish and macro-zooplankton (Table 3B).

\section{ZOOPLANKTON}

Zooplankton concentrations including C. finmarchicus, krill and amphipods were generally low with an average weight of $4.8 \mathrm{~g} / \mathrm{m}^{2}$, $4.0 \mathrm{~g} / \mathrm{m}^{2}, 6.0 \mathrm{~g} / \mathrm{m}^{2}$ for the years 2009,2010 and 2012. In general, the plankton concentrations were lowest in the central Norwegian Sea and highest in the south western part and east of Iceland in the frontal area between the warm Atlantic water and the colder Arctic water. C. finmarchicus was generally found in small concentrations in the western survey area, while C. hyperboreus was collected in the northern and northwestern part of the Norwegian Sea. Krill and amphipods were not found or in very small quantities in most areas except in the westernmost areas.

\section{DISCUSSION}

A compelling result from this study is the more frequent toothed whale sightings, in particular of killer- and pilot whales, in the Norwegian Sea compared to previous historic sighting surveys (Hammond and Lockyer, 1988; Buckland et al., 1993; Abend and Smith, 1999; Nøttestad and Olsen, 2004; Øien, 2013). Fin whales seemed to have switched toward a fish prey vs. a diet consisting of krill and amphipods only few years earlier (Nøttestad et al., 2014a). There have been a change in distribution and reduction in biomass of krill and amphipods in the Norwegian Sea during the last 10-15 years (Dalpadado et al., 1998; Melle et al., 2004). Quantifying macro-zooplankton such as krill and amphipods using vertical hauls with WP2 nets is difficult since these nets with such small opening and mesh size are generally not regarded as efficient sampling gear for macro-zooplankton including krill (except the sub-adult stages). Nevertheless, we also used more qualitative data from our extensive numbers of trawl hauls stations to document presence or absence of krill and amphipods caught during pelagic trawling close to the surface in relation to marine mammal sightings. Humpback whales were found in very low numbers and no overlap was detected between their distribution and potential prey species. Findings from 2006 to 2007 showed a different picture with much higher sighting numbers and a distribution toward the northernmost waters of the Norwegian Sea associated with NSS herring (Nøttestad et al., 2014a).

The high numbers of killer whales and pilot whales sighted increased substantially from year to year during our study. Killer whales were associated with NEA mackerel, which is in line with results also found in the same area during 2006/2007 (Nøttestad et al., 2014b). Mean group size of killer whales was between 5.1 and 9.2 animals from 2009 to 2012, which is comparable with mean group size $=8.2$ animals found in the Norwegian Sea in summers 2006 and 2007 (Nøttestad et al., 2014b). The collective behavior of killer whales thus seems to be fine-tuned to the schooling behavior and aggregation level of their dominant mackerel prey (Nøttestad et al., 2002, 2014b). Pilot whales are opportunistic feeders that may exploit locally abundant prey, but they are traditionally regarded as consumers of squid (Nøttestad and Olsen, 2004; Olson, 2009). Pilot whales prey on some commercially important fish such as NEA mackerel and NSS herring, and appear to be able to adjust their diet in response to changes in prey abundance (Desportes and Mouritsen, 1993). In our study, pilot whales were to a large degree found associated with NSS herring and were found in groups of variable average size ranging from 5.2 to 17.0 animals, probably adjusted to their schooling 
prey species, but they were also found to be associated with high zooplankton concentrations, as the only cetacean species in our study. This species was also associated with shallow bottom regions $(<300 \mathrm{~m})$ which is not particularly associated with their traditionally dominant prey as squid are predominantly found on much deeper waters. The influence of warm Atlantic water has been very strong in the Norwegian Sea during the period from 2009 to 2012 (Beszczynska-Möller and Dye, 2013). The warm surface waters combined with low concentrations of mesoand macro zooplankton such as copepods, krill (Meganyctiphanes norvegica, Thysonoessa inermis, and Thysonoessa longicaudata) and amphipods (Themisto libellula) and a large mackerel stock feeding in the Norwegian Sea during summer, has expanded their spatial distribution to new and previously unknown territories far to the north and west. Nevertheless, the decrease in zooplankton biomass including Calanus finmarchicus in the Norwegian Sea may have stabilized after 2009, and in recent years there has been a tendency of increase (Huse et al., 2012; Broms, 2014), which may have affected the distribution and aggregation of pelagic fish and furthermore presence and distribution of marine mammal species. NSS herring has also responded to the warmer waters by feeding further north and northwest in summer than earlier years (ICES, 2013a). Since presence of mackerel and NSS herring has steadily increased in northern waters from 2009 to 2012, including along the Polar Front between Atlantic and Arctic water masses, this has led to increased availability of pelagic fish for the cetaceans (Nøttestad and Olsen, 2004; ICES, 2014; Nøttestad et al., 2014c). It seems clear that the high abundance of pelagic fish species estimated to be around $15 \mathrm{Mt}$ have attracted more feeding toothed whales such as killer and pilot whales to the Norwegian Sea ecosystem.

Sperm whales were sighted in modest numbers and mainly occurring as solitary individuals during our sighting surveys. There is little scientific knowledge available on the status of abundance and distribution of their main cephalopod prey species (G. fabricii) (Roper et al., 2010). However, there are indications of decreasing cephalopods abundance including G. fabricii over the past decades (Wiborg et al., 1982; Gardiner and Dick, 2010).

Historically, the Norwegian Sea ecosystem has been important for baleen whale feeding during summer (Jonsgård, 1966, 1968). The baleen whales observed during this study are found to be more associated with pelagic fish compared to meso- and macro zooplankton (see Nøttestad et al., 2014a), suggesting a temporal shift in prey distribution. Elevated sub-surface temperatures documented in the Norwegian Sea during the last few years compared to 10-20 years ago (Skagseth and Mork, 2012; BeszczynskaMöller and Dye, 2013; ICES, 2013c), may have influenced distribution and aggregation of potential prey species for marine mammals feeding within this ecosystem. We found that both fin whale and minke whale, among the most abundant baleen whales in our study, were significantly associated with NSS herring as also found along the Barents Sea shelf edge (Skern-Mauritzen et al., 2009) and not correlated with macro-zooplankton such as krill as dominant prey species in earlier periods based on direct stomach samples (Jonsgård, 1966, 1968). This is partly in contrast to a study performed in the Norwegian Sea during summers 2006-2007 where fin- and humpback whales were found correlated with the presence of macro-zooplankton in cold Arctic water (Nøttestad et al., 2014a). This change suggests that macro-zooplankton is becoming less available and pelagic fish is becoming more available as dominant prey in the Norwegian Sea during the active feeding period in summer. Higher temperatures combined with less abundance of meso- and macro zooplankton found in our study from 2009 to 2012 compared to earlier studies (Dalpadado et al., 1998; Melle et al., 2004), suggest suboptimal conditions for species such as C. finmarchicus, krill and amphipods in the Norwegian Sea. Cetaceans preying on these species will then follow and shift their distribution to obtain more optimal feeding on these species. Low group sizes of both finand humpback whales observed from 2009 to 2012 coincide with similar findings from 2006 and 2007, suggesting that these baleen whale species mainly hunt solitary or in small groups within the Norwegian Sea ecosystem in summer (Nøttestad et al., 2014a).

The Norwegian Sea has traditionally been an important migration corridor for baleen whales toward northern feeding grounds and to a lesser extent vital as feeding grounds for minke-, humpback- and fin whales (see Nøttestad and Olsen, 2004; Clapham, 2009; Øien, 2013; Nøttestad et al., 2014a). A reduction in, e.g., minke whale abundance is observed in the Norwegian Sea during the last decade (Øien, 2013). Prey species such as krill and amphipods may have shifted their spatial distribution to more northern latitudes (Buchholtz et al., 2010; Kraft et al., 2013), which probably influences the minke whales main migration patterns. The minke and fin whales are regarded as opportunistic in their prey choice, leading us to believe that a preference toward NSS herring and not zooplankton for the animals residing in our study area is probably not an unusual finding. Vikingsson et al. (2014) found that minke whales in Icelandic waters have shifted their distribution and diet composition during the last years from a diet dominated by sandeel and macro-zooplankton to a fish diet dominated of herring and gadoids. Cold water species such as krill and capelin were less present in the minke whale diet, coinciding with our results on spatial overlap, where herring, in both studies, were found to be the most important prey species for minke whales in recent years. Despite large abundance of available prey species such as NSS herring and blue whiting in the study area, the fin whales sighted were predominantly swimming far to the north, and were found associated with the cold water species capelin. The sighted humpback whales in our study were not found to be associated with any registered prey species. This might indicate low feeding activities for this species within this region; however, the statistical data was represented with few humpback whale observations.

Toothed whales in general and group living dolphins in particular, apply coordinated hunting strategies, which is suited to capture smaller and less dense concentrations of pelagic fish. Killer whales and pilot whales can also circumvent and manipulate the anti-predator behavior of mackerel and NSS herring to their own benefit by packing looser shoals and aggregations to become denser schools, as well as adjust their group size to prevailing patchiness and school size of pelagic fish (Nøttestad et al., 2014b). This might be important factors influencing the success of these species in this region. Due to low concentrations and densities of meso- and macro-zooplankton during summer, 
pelagic fish are forced to spread out in smaller and looser shoals and concentrations in order to optimize their own feeding for dominant and easily accessible prey species (Fernö et al., 1998). When pelagic fish are more evenly distributed in small aggregations, they become less available for solitary baleen whales, which dominated in our sighting data. Their hunting technique is much less cost-efficient when schooling fish and swarms of krill and amphipods do not to appear in dense patches.

\section{ACKNOWLEDGMENTS}

This project was financed by the former Norwegian Ministry of Fisheries and Coastal Affairs (Norwegian Ministry of Trade, Industry and Fisheries) and the Institute of Marine Research, Bergen, Norway. We would like to thank the skippers and crew onboard the M/V "Libas," M/V "Eros" and M/V "Brennholm" and R/V "G.O. Sars" for excellent collaboration and practical assistance during the ecosystem surveys in 2009, 2010, and 2012 in the Norwegian Sea. We would also like to thank all the dedicated marine mammal observers onboard the vessels and Karen Gjertsen at the Institute of Marine Research for designing and producing the maps.

\section{REFERENCES}

Abend, A. G., and Smith, T. D. (1999). Review of Distribution of the Long-Finned Pilot Whale (Globicephala Melas) in the North Atlantic and Mediterranean. NOAA Technical Memorandum NMFS-NE-117. Boston, MA: Woods Hole, 28.

Beszczynska-Möller, A., and Dye, S. R. (2013). ICES Report on Ocean Climate 2012. ICES Cooperative Research Report No. 321, ed Emory D. Andersen, Copenhagen.

Broms, C. (2014). "Zooplankton in the Norwegian Sea," in Havforskningsrapporten 2014, eds I. E. Bakketeig, H. Gjøsæter, M. Hauge, B. H. Sunnset and K. Ø. Toft (Bergen: Fisken og havet, særnr), 1-2014

Buchholtz, F., Buchholtz, C., and Weslawsky, J. (2010). Ten years after: krill as indicator of changes in the macro-zooplankton communities in two Arctic fjords. Polar Biol. 33, 101-113. doi: 10.1007/s00300-009-0688-0

Buckland, S. T., Bloch, D., Cattanach, K. L., Gunnlaugsson, T., Hoydal, K., Lens, S., et al. (1993). Distribution and abundance of long-finned pilot whales in the North Atlantic, estimated from NASS-1987 and NASS-89 data. Rep. Int. Whal. Comm. 14, 33-50.

Burek, K. A., Gulland, F. M. D., and O'Hara, T. M. (2008). Effects of climate change on arctic marine mammal health. Ecol. Appl. 18, 126-134. doi: 10.1890/060553.1

Christensen, I., Haug, T., and Øien, N. (1992). Seasonal distribution, exploitation and present abundance of stocks of large baleen whales (Mysticeti) and sperm whales (Physeter macrocephalus) in Norwegian and adjacent waters. ICES J. Mar. Sci. 49, 341-355. doi: 10.1093/icesims/49.3.341

Clapham, P. J. (2009). "Humpback whale Magaptera novaeangliae," in Encyclopedia of Marine Mammals, 2nd Edn., eds W. F. Perrin, B. Wursig, and J. G. M. Thewiessen (San Diego, CA: Thewiessen Academic Press), 582-585. doi: 10.1016/B978-0-12-373553-9.00135-8

Dalpadado, P., Ellertsen, B., Melle, W., and Skjoldal, H. R. (1998). Summer distribution patterns and biomass estimates of macrozooplankton and micronekton in the Nordic Seas. Sarsia 83, 103-116.

Desportes, G., and Mouritsen, R. (1993). Preliminary results on the diet of longfinned pilot whales off the Faroe Islands. Rep. Int. Whal. Comm. 14, 305-324.

Evans, P. G. H., Pierce, G., and Panigada, S. (2010). Climate change and marine mammals. J Mar. Biol. Assoc. UK 90, 1483-1487. doi: 10.1017/S002531541 0001815

Ferguson, S. H. (2009). Killer whales on the rise in the Canadian Arctic. Circle 4, $20-23$.

Fernö, A., Pitcher, T. J., Melle, V., Nøttestad, L., Mackinson, S., Hollingworth, C., et al. (1998). The challenge of the herring: making optimal collective spatial decisions. Sarsia 83, 149-167.
Gardiner, K., and Dick, T. A. (2010). Arctic cephalopod distributions and their associated predators. Polar Res. 29, 209-227. doi: 10.1111/j.1751-8369. 2010.00146.x

Gjøseter, H., Dalpadado, P., Hassel, A., and Skjoldal, H. R. (2000). A comparison of performance of WP2 and MOCNESS. J. Plank Res. 22, 1901-1908. doi: 10.1093/plankt/22.10.1901

Hammond, P. S., and Lockyer, C. (1988). Distribution of killer whales in the eastern North Atlantic. Rit. Fiskideildar 11, 25-35.

Holst, J. C., Røttingen, I., and Melle, W. (2004). "The herring," in The Norwegian Sea Ecosystem, eds H. R. Skjoldal, O. A. Misund, R. Sætre, A. Fernø, and I. Røttingen (Trondheim: Tapir Academic Press), 203-226.

Huse, G., Holst, J. C., Utne, K. R., Nøttestad, L., Melle, W., Slotte, A., et al. (2012). Effects of interactions between fish populations on ecosystem dynamics in the Norwegian Sea-results of the INFERNO project. Mar. Biol. Res. 8, 415-419. doi: 10.1080/17451000.2011.653372

ICES (International Council for the Exploration of the Sea). (2013a). Advice for 2014. 9.4.17 Mackerel in the Northeast Atlantic (Combined Southern, Western and North Sea Spawning Components). Copenhagen.

ICES (International Council for the Exploration of the Sea). (2013b). Report of the Working Group on Widely Distributed Stocks (WGWIDE). Copenhagen: ICES CM 2013/ACOM:15, 950.

ICES (International Council for the Exploration of the Sea). (2013c). ICES Report on Ocean Climate 2012. Prepared by the Working Group on Oceanic Hydrography. Copenhagen: ICES Cooperative Research Report No. 321, 74.

ICES (International Council for the Exploration of the Sea). (2014). Report of the Working Group on Widely Distributed Stocks (WGWIDE). Copenhagen: ICES CM 2014/ACOM:15, 971.

IPCC (Intergovernmental Panel on Climate Change). (2007). Climate Change 2007, Fourth Assessment Report. Cambridge; New York: Cambridge University Press. Available online at: http://www.ipcc.ch.

IPCC (Intergovernmental Panel on Climate Change). (2014). Climate Change 2014, Fifth Assessment Report. Cambridge; New York: Cambridge University Press. Available online at: http://www.ipcc.ch.

IWC (International Whaling Commission). (1997). Report of the IWC workshop on climate change and cetaceans. Rep. Int. Whal. Comm. 47, 293-313.

IWC (International Whaling Commission). (2009). Report of the IWC workshop on climate change and cetaceans. IWC/SC/61/Report 4, 1-31.

Jonsgård, Å. (1966). Biology of the North Atlantic fin whale Balenoptera physalus L.-Taxonomy, distribution, migration and food. Hvalr. Skr. 49, 1-62.

Jonsgård, A. (1968). A review of Norwegian biological research on whales in the northern North Atlantic Ocean after the second world war. Norsk Hvalfangsttidende 57, 164-167.

Kovacs, K. M., Lydersen, C., Overland, J. E., and Moore, S. E. (2011). Impacts of changing sea-ice conditions on Arctic marine mammals. Mar. Biodiv. 41, 181-194. doi: 10.1007/s12526-010-0061-0

Kraft, A., Nöthig, E. M., Bauerfeind, E., Wildish, D. J., Pohle, G. W., Bathmann, U. V., et al. (2013). First evidence or reproductive success in a southern invader species indicates possible community shifts among Arctic zooplankton. MEPS 493, 291-296. doi: 10.3354/meps 10507

Laidre, K. L., Stirling, I., Lowry, L., Wiig, Ø., Heide-Jørgensen, M. P., and Fergusen, S. H. (2008). "Quantifying the sensitivity of arctic mammals to climate-induces habitat change. In Huntington, H. P., and Moore, S. E. (eds). Arctic marine mammals and climate change. Ecol. Appl. 18 (Suppl.), S97-S125.

Lawson, J. W., and Gosselin, J. F. (2009). Distribution and preliminary abundance estimates for cetaceans seen during Canada's Marine Megafauna Survey-A component of the 2007 TNASS. Can. Sci. Adv. Ser. Res. 031, 28.

Learmonth, J. A., MacLeod, C. D., Santos, M. B., Pierce, G. J., Crick, H. Q. P., and Robinson, R. A. (2006). Potential effects on a miniature ocean: the highly diverse, highly impacted Mediterranean Sea. Ocean Mar. Biol. 44, 431-464.

MacLeod, C. D. (2009). Global climate change, range changes and potential implications for the conservation of marine cetaceans, a review and synthesis. End. Spec. Res. 7, 125-136. doi: 10.3354/esr00197

Melle, W., Ellertsen, B., and Skjoldal, H. R. (2004). "Zooplankton: the link to higher trophic levels," in The Norwegian Sea Ecosystem, eds H. R. Skjoldal, R. Sætre, A. Fernö, O. A. Misund, and I. Røttingen (Trondheim: Tapir Academic Press), 137-202. 
Moore, S. E., and Huntington, H. P. (2008). Arctic marine mammals and climate change: impact and resiliance. Ecol. Appl. 18, 157-165. doi: 10.1890/060571.1

NAMMCO (North Atlantic Marine Mammal Commission). (2013). "Report of the twenty second meeting of the Scientific Committee," in NAMMCO Annual Report (Tromsø), 305.

Nøttestad, L., Fernö, A., and Axelsen, B. E. (2002). Digging in the deep: killer whales' advanced hunting tactic. Polar Biol. 25, 939-941. doi: 10.1007/s00300002-0437-0

Nøttestad, L., and Olsen, E. (2004). "Whales and seals: top predators in the ecosystem," in The Norwegian Sea Ecosystem, eds H. R. Skjoldal, O. A. Misund, R. Sætre, A. Fernø, and I. Røttingen (Trondheim: Tapir Academic Press), 395-434.

Nøttestad, L., Salthaug, A., Johansen, G. O., Oskarsson, G., Anthonypillai, V., Tangen, Ø., et al. (2014c). "Cruise report from the coordinated ecosystem survey (IESSNS) with M/V "Brennholm," M/V "Vendla," M/V "Finnur Fríği" and R/V "Árni Friğriksson" in the Norwegian Sea and surrounding waters, 2 July-12 August 2014," in Working Document Presented to ICES WGWIDE (Copenhagen), 49.

Nøttestad, L., Sivle, L. D., Krafft, B. A., Langård, L., Anthonypillai, V., Bernasconi, M., et al. (2014a). Ecological aspects of fin whale and humpback whale distribution during summer in the Norwegian Sea. Mar. Ecol. 35, 221-232. doi: $10.1111 /$ maec. 12075

Nøttestad, L., Sivle, L. D., Krafft, B. A., Langård, L., Anthonypillai, V., Bernasconi, M., et al. (2014b). Prey selection of offshore killer whales Orcinus orca in the Northeast Atlantic in late summer: spatial associations with mackerel. Mar. Ecol. Prog. Ser. 499, 275-283. doi: 10.3354/meps 10638

Øien, N. (1988). "The distribution of killer whales (Orcinus orca) in the North Atlantic based on Norwegian catches, 1938-1981, and incidental sightings, 1967-1987,” in Rit Fiskideildar, Vol XI, eds J. Sigurjónsson and S. Leatherwood (Reykjavík: HAFRO, Marine Research Institute in Iceland), 5-77.

Øien, N. (2003). "Distribution and abundance of large whales in the Northeast Atlantic, 1995," in Working Paper NAMMCO SC/11/MF/10 to the Working Group on Minke and Fin Whales (Copenhagen), 26.

Øien, N. (2013). Report of the Norwegian 2011 survey for minke whales within the Small Management Area EW-the eastern Norwegian Sea. SC/64/RMP 5. Int. Whal. Comm. Sci Comm. 8, 1-6.

Olson, P. A. (2009). "Pilot whales Globicephala melas and G. macrorhyncus," in Encyclopedia of Marine Mammals, 2nd Edn., eds W. P. Perrin, B. Würsig, and J. G. M. Thewissen, (London: Academic Press), 847-852.

Palka, D. L., and Hammond, P. S. (2001). Accounting for responsive movement in line transect estimates of abundance. Can. J. Fish Aquat. Sci. 58, 777-787. doi: 10.1139/f01-024

Pike, D. G., Gunnlaugsson, T. H., Øien, N., Desportes, G., Vikingsson, G. A., Paxton, C. G. M., et al. (2005). Distribution, Abundance and Trends in Abundance of Fin and Humpback Whales In the North Atlantic. ICESCM2005/R:12, Copenhagen: ICES.

Roper, C. F. E., Jorgensen, E. M., Katugin, O. N., and Jereb, P. (2010). "Family gonatidae," in Cephalopods of the World. An Annotated and Illustrated Catalogue of Cephalopod Species Known to Date, Vol. 2, eds P. Jereb and C. F. E. Roper (Rome: Myopsid and Oegopsid Squids), 200-222.

Schwartz, L. K., Gerrodette, T., and Archer, F. I. (2010). Comparison of closing and passing mode from a line-transect of delphinids in the eastern Tropical Pacific Ocean. J. Cetac Res Manage. 11, 253-265.

Sigurjónsson, J., Lyrholm, T., Leatherwood, S., Jónsson, E., and Vikingson, G. (1988). Photoidentification of killer whales off Iceland 1981 through 1986. Rit Fiskideildar 11, 1185-1189.

Similä, T., Holst, J. C., and Christensen, I. (1996). Occurrence and diet of killer whales in northern Norway: seasonal patterns relative to the distribution and abundance of Norwegian spring-spawning herring. Can. J. Fish Aquat. Sci. 53, 769-779. doi: 10.1139/f95-253

Simmonds, M. P., and Elliot, W. J. (2009). Climate change and cetaceans: concerns and recent developments. J. Mar. Biol. Assoc. UK 89. 203-201. doi: 10.1017/S0025315408003196

Simon, M., Ugarte, F., Wahlberg, M., and Miller, L. (2006). Icelandic killer whales Orcinus orca use a pulsed call suitable for manipulating the schooling behaviour of herring Clupea harengus. Bioacoust 16, 57-74. doi: 10.1080/09524622.2006.9753564

Skagseth, Ø., and Mork, K. A. (2012). Heat content in the Norwegian Sea, 19952010. ICES J. Mar. Sci. 69, 826-832. doi: 10.1093/icesjms/fss026

Skern-Mauritzen, M., Skaug, H. J., and Øien, N. (2009). Line transects, environmental data and GIS: cetacean distibution, habitat and prey selection along the Barents Sea shelf edge. NAMMCO Sci. Publ. 7, 179-200. doi: 10.7557/ 3.2713

Skjoldal, H. R., Sætre, R., Fernö, A., Misund, O. A., and Røttingen, I. (eds). (2004). The Norwegian Sea Ecosystem. Trondheim: Tapir Academic Press, 559.

Smith, B. D., and Reeves, R. R. (2010). Freshwater-dependent cetaceansintegrating climate change-related impacts from mountain to sea. Climate Change and European Cetaceans. Whale watcher. J. Am. Cet. Soc. 39, 25-29.

Vikingsson, G. A., Elvarsson, B. P., Ólafsdóttir, D., Sigurjónsson, J., Chosson, V., and Galan, A. (2014). Recent changes in the diet composition of common minke whales (Balaenoptera acutorostrata) in Icelandic waters. A consequence of climate change? Mar. Biol. Res. 10, 138-152. doi: 10.1080/17451000.2013. 793812

Vikingsson, G. A., Pike, D. G., Desportes, G., Øien, N., Gunnlaugsson, T. H., and Bloch, D. (2009). Distribution and abundance of fin whales (Balaenoptera physalus) in the Northeast and Central Atlantic as inferred from the North Atlantic Sightings Surveys 1987-2001. NAMMCO Sci. Publ. 7, 49-72. doi: $10.7557 / 3.2705$

Wiborg, K. F., Gjøsæter, J., and Beck, I. M. (1982). The Squid Gonatus Fabricii: Investigations in the Norwegian Sea and Western Barents Sea. ICES C.M. 1984/K:19. Copenhagen: ICES.

Würsig, B., Reeves, R. R., and Ortega-Urtiz, J. G. (2002). "Global climate change and marine mammals," in Marine Mammals-Biology and Conservation, eds P. G. H. Evans and J. A. Raga (New York, NY: Kluwer Academic/Plenum Publishers), 589-608.

Conflict of Interest Statement: The authors declare that the research was conducted in the absence of any commercial or financial relationships that could be construed as a potential conflict of interest.

Received: 31 October 2014; accepted: 02 December 2014; published online: 05 January 2015.

Citation: Nøttestad L, Krafft BA, Anthonypillai V, Bernasconi M, Langård L, Mørk HL and Fernö A (2015) Recent changes in distribution and relative abundance of cetaceans in the Norwegian Sea and their relationship with potential prey. Front. Ecol. Evol. 2:83. doi: $10.3389 /$ fevo.2014.00083

This article was submitted to Interdisciplinary Climate Studies, a section of the journal Frontiers in Ecology and Evolution.

Copyright (c) 2015 Nøttestad, Krafft, Anthonypillai, Bernasconi, Langård, Mørk and Fernö. This is an open-access article distributed under the terms of the Creative Commons Attribution License (CC BY). The use, distribution or reproduction in other forums is permitted, provided the original author(s) or licensor are credited and that the original publication in this journal is cited, in accordance with accepted academic practice. No use, distribution or reproduction is permitted which does not comply with these terms. 